\title{
The Use of Google Classroom To Improve Student's Learning Activity Class III Students of SD Muhammadiyah Purin
}

\author{
Rini Setyowati \\ SD Muhammadiyah Purin \\ rini.umi.kanza@gmail.com
}

\section{Article History}

accepted 01/11/2020

approved 08/11/2020

published $15 / 11 / 2020$

\begin{abstract}
The purpose of this research was to improve student's learning activity of theme 4 sub theme 1 the use of Google Classroom aplication for grade III SD Muhammadiyah Purin. Classroom Action Reseacrh methode implemented in 3 cycles which consists of: planning, implementation, observation and reflection. Technique and data collection of this reseacrh use of descriptive analysis technique of observation sheet student's activity in the learning, score list and observation sheet. The result of this research was use of Google Classroom and Kahoot has increased of student's activity in each cycle. In cycle I to cycle II and repeat cycle III was increased in cycle I activestudent was 12 students or $54,55 \%$, not active students 10 students or $45,45 \%$,in cycle 2 active students increased 20 students or $91 \%$ not active's students 2 studentsaor 9,09\% and cycle 3 wa active's students 21 students atau 96\% and not active's students a student. The conclution that can be outcome use Google classroom aplication and Kahoot can increased student's activity in the learning
\end{abstract}

Keyword: student activity, google classroom dan kahoot

\begin{abstract}
Abstrak
Penelitian ini bertujuan untuk meningkatkan keaktifan siswa dalam pembelajaran tema 4 sub tema 1 dengan menggunakan Google classroom pada siswa kelas III SD Muhammadiyah Purin. Metode Penelitian Tindakan Kelas ini dilaksanakan dengan tiga siklus yang terdiri dari: perencanaan, pelaksanaan, observasi dan refleksi. Teknik dan alat pengumpulan data pada penelitian ini menggunakan teknik analisis deskriptif terhadap data berupa dokumen lembar observasi keaktifan siswa dalam pembelajaran, daftar nilai dan lembar observasi. Hasil penelitian menunjukkan bahwa dengan penggunaan Google classroom dan Kahoot terjadi suasana pembelajaran yang menyenangkan sehingga keaktifan siswa meningkat, yaitudari hasil siklus I ke Siklus II dan pengulangan siklus III terdapat peningkatan, pada siklus 1 jumlah siswa yang aktif adalah 12 siswa atau $54,55 \%$, tidak aktif sebanyak 10 siswa atau 45,45\%, sedangkan pada siklus 2 terjadi peningkatan keaktifan siswa yaitu menjadi 20 siswa atau $91 \%$ dan tidak aktif sebanyak 2 siswa atau 9,09\% pada siklus 3 Kemudian diulangi lagi pada siklus 3 jumlah siswa yang aktif adalah 21 siswa atau 96\% dan jumlah siswa yang tidak aktif adalah 1 siswa. Disimpulkan bahwa penggunaan Google Classroom dan Kahoot dalam pembelajaran daring dapat meningkatkan keaktifan siswa dalam pembelajaran.
\end{abstract}

Kata kunci: keaktifan siswa, google classroom dan kahoot

Social, Humanities, and Education Studies (SHEs): Conference Series https://jurnal.uns.ac.id/shes

p-ISSN 2620-9284

e-ISSN 2620-9292 


\section{PENDAHULUAN}

Keaktifan siswa dalam kegiatan belajar tidak lain adalah untuk mengkonstruksi pengetahuan mereka sendiri. Mereka aktif membangun pemahaman atas persoalan atau segala sesuatu yang mereka hadapi dalam proses pembelajaran. Dalam Kamus Besar Bahasa Indonesia aktif berarti giat (bekerja, berusaha). Keaktifan diartikan sebagai hal atau keadaan dimana siswa dapat aktif. Rousseau dalam (Sardiman, 1986: 95) menyatakan bahwa setiap orang yang belajar harus aktif sendiri, tanpa ada aktifitas proses pembelajaran tidak akan terjadi. Thorndike mengemukakan keaktifan belajar siswa dalam belajar dengan hukum "law of exercise"-nya menyatakan bahwa belajar memerlukan adanya latihan-latihan dan Mc Keachie menyatakan berkenaan dengan prinsip keaktifan mengemukakan bahwa individu merupakan "manusia belajar yang aktif selalu ingin tahu" (Dimyati,2009:45). Segala pengetahuan harus diperoleh dengan pengamatan sendiri, pengalaman sendiri, penyelidikan sendiri, dengan bekerja sendiri dengan fasilitas yang diciptakan sendiri , baik secara rohani maupun teknik.

Sejak diberlakukannya Kebijakan pemerintah pada tangggal 16 Maret 2020 tentang pembelajaran yang berbasis online. Hal ini sesuai dengan Menteri Pendidikan dan Kebudayaan Republik Indonesia terkait Surat Edaran Nomor 4 Tahun 2020 tentang Pelaksanaan Kebijakan Pendidikan dalam Masa Darurat Penyebaran Corona Virus Disease (COVID-19). Sistem pembelajaran dilaksanakan melalui perangkat personal computer (PC) atau laptop yang terhubung dengan koneksi jaringan internet. Banyak berbagai macam media pembelajaran yang ada namun belum digunakan guru secara maksimal. Salah satunya adalah penggunaan media aplikasi google classroom dapat dimanfaatkan sebagai media pembelajaran untuk membantu meningkatkan hasil belajar siswa. Desain dari Google Classroom sudah tidak asing lagi bagi siswa karena mereka sudah menggunakan beberapa produk dari Google via akun Google Apps (Izenstark dan Leahy, 2015).

Penggunaan Google Classroom ini sesungguhnya mempermudah guru dalam mengelola pembelajaran dan menyampaikan informasi secara cepat dan akurat kepada siswa (Hardiyana, 2015). Google Classroom di desain untuk empat pengguna yaitu pengajar, siswa, wali dan administrator. Kelebihan aplikasi Google Classroom dibandingan dengan aplikasi lain yaitu aplikasi Google Classroom dapat digunakan untuk membuat dan mengelola kelas, tugas, nilai serta memberikan masukan secara langsung. Siswa dapat memantau materi dan tugas kelas, berbagi materi dan berinteraksi dalam kelas atau melalui email, mengirim tugas dan mendapatkan masukan nilai secara langsung. Pembelajaran dengan penggunaan Google Classroom ini memiliki kelebihan untuk mempermudah siswa dalam belajar. Berdasarkan jurnal penelitian Abd Rozak dan Azkia

Dengan demikian, tujuan dari penelitian ini adalah untuk mengetahui apakah penggunaan aplikasi google classroom ini dapat meningkatkan keaktifan belajar tema 4 hak dan kewajiban sub tema 1 hak dan kewajiban dirumah siswa kelas III SD Muhammadiyah Purin Tahun pelajaran 2020 / 2021 Sehingga hasil penelitian ini juga dapat diketahui hasil peningkatan keaktifan siswa melalui instrumen penelitian yang diberikan. Adapun rumusan masalah penelitian adalah bagaimana penggunaan aplikasi google classroom dapat meningkatkan keaktifan belajar tema 4 hak dan keawajiban sub tema 1 hak dan kewajiban dirumah pembelajaran 1 siswa kelas III SD Muhammadiyah Purin tahun pelajaran 2020 / 2021.

\section{METODE}

Penelitian ini adalah Penelitian tindakan Kelas dengan menerapkan model pembelajaran discovery learning. Penelitian Tindakan Kelas ini terdiri dari empat tahapan dasar yaitu perencanaan, pelaksanaan, pengamatan dan refleksi. Analisis penelitian adalah deskripsi kuantitatif dimana dalam penelitian ini selain menyajikan 
hasil berupa data. Teknik pengumpulan data yang dilakukan dengan observasi, daftar nilai dan lembar observasi.

\section{HASIL DAN PEMBAHASAN}

Pada siklus 1 pembelajaran dilaksanakan untuk pokok bahasan keaktifan siswa dalam pembelajaran. Serta perbaikan pembelajaran pada siklus I merupakan perbaikan pembelajaran dari hasil pembelajaran yang dilaksanakan sebelumnya. Dalam rencana pelaksanaan pembelajaran dilakukan dengan Google Classroom yaitu siswa dimasukkan dalam kelas virtual dengan menggunakan platform dari Google meet. Berdasarkan proses perbaikan pembelajaran dengan menerapkan penggunaan Google classroom pada siklus I diperoleh hasil sebagai berikut sesuai tabel 1.:

Tabel 1. Keaktifan Siswa dalam Pembelajaran Siklus I

\begin{tabular}{cccc}
\hline interval & Frekuensi & $\%$ & Kategori \\
\hline $31-40$ & 5 & $22,73 \%$ & Sangat Aktif \\
$21-30$ & 7 & $31,82 \%$ & Aktif \\
$11-20$ & 8 & $36,36 \%$ & Cukup Aktif \\
$0-10$ & 2 & $9,09 \%$ & Kurang Aktif \\
Rata - rata & $77 \%$ & Aktif \\
keaktifan & & \\
\hline
\end{tabular}

Berdasarkan tabel 1. diperoleh hasil yaitu dari 22 siswa yang memperoleh nilai 31-40 sebanyak 5 Siswa(22,73\%), nilai $21-30$ sebanyak 7 anak $(31,82 \%)$, nilai $11-20$ sebanyak 8 anak $(36,36 \%)$ dan nilai $0-10$ sebanyak 2 anak $(9,09 \%)$ dengan kategori kurang aktif. Selebihnya tergambar bahwa keaktifan rata rata siswa dalam pembelajaran dalam tingkat keberhasilan $77 \%$. Hal ini sesuai dengan gambar 1 yaitu:

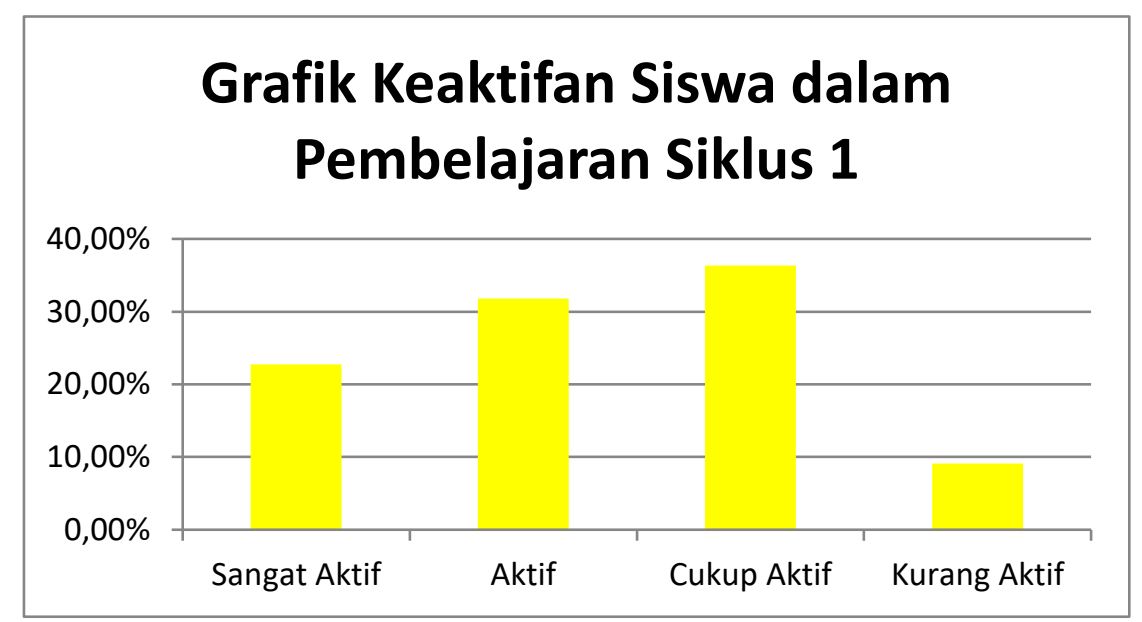

Gambar 1. Grafik Keaktifan Siswa dalam Pembelajaran Siklus 1

Berdasarkan gambar 1. dapat diketahui keaktifan siswa selama perbaikan pembelajaran pada siklus I, dapat dilihat perkembangan hasil belajar siswa ratarata pada interval 7 dengan presentasi $32,64 \%$. Ini artinya keaktifan siswa dalam 
pembelajaran sudah mulai meningkat tetapi untuk keaktifan siswa dalam pengumpulan tugas masih rendah dibanding dengan nilai rata-rata ulangan harian sebelumnya mengalami kenaikan. Namun demikian masih diperlukan perbaikan untuk menjadi lebih baik.

Berdasarkan data temuan kekurangan dari kegiatan pembelajaran siklus 1, maka tindak lanjut yang perlu dilakukan dalam siklus 2 yaitu menambah kegiatan yang dapat mengaktifkan siswa dalam pembelajaran. Memantau siswa secara intensif agar mengikuti pembelajaran dengan baik, tidak mengganggu teman yang lain, serta dapat memberikan bimbingan kepada siswa yang kesulitan secara individu. Siklus kedua merupakan perbaikan pembelajaran dari hasil pembelajaran yang dilaksanakan pada pertemuan pertama. Sesuai dengan hasil observasi yang didapatkan dalam pelaksanaan pertemuan pertama. Dalam rencana pelaksanaan pembelajaran ini dilakukan sesuai dengan langkah-langkah pembelajaran Discovery learning. Dari hasil pengamatan diperoleh data $91 \%$ mencapai keaktifan. Adapun hasil prestasi belajar sebagai berikut:

Tabel 2. Keaktifan Siswa dalam Pembelajaran Siklus II

\begin{tabular}{cccc}
\hline interval & Frekuensi & $\%$ & Kategori \\
\hline $31-40$ & 11 & $45,45 \%$ & Sangat Aktif \\
$21-30$ & 9 & $40,91 \%$ & Aktif \\
$11-20$ & 1 & $4,54 \%$ & Cukup Aktif \\
$0-10$ & 1 & $4,54 \%$ & Kurang Aktif \\
Rata - rata keaktifan & $82,73 \%$ & \\
\hline
\end{tabular}

Berdasarkan tabel di atas diperoleh hasil yaitu dari 22 siswa yang memperoleh nilai 31 - 40 sebanyak 10 Siswa $(45,45 \%)$ dengan kategori sangat aktif, nilai 21 - 30 sebanyak 9 siswa $(40,91 \%)$ dengan kategori aktif, nilai $11-20$ sebanyak 1 siswa (4,54\%) dengan kategori cukup aktif, sedangkan 1 anak (4,54\%) dengan kategori kurang aktif. Selebihnya tergambar bahwa nilai rata-rata keaktifan siswa 82,73 dengan batas KKM 65, tingkat keberhasilan $91 \%$. Tabel di atas dapat disajikan dalam bentuk gambar 2 .

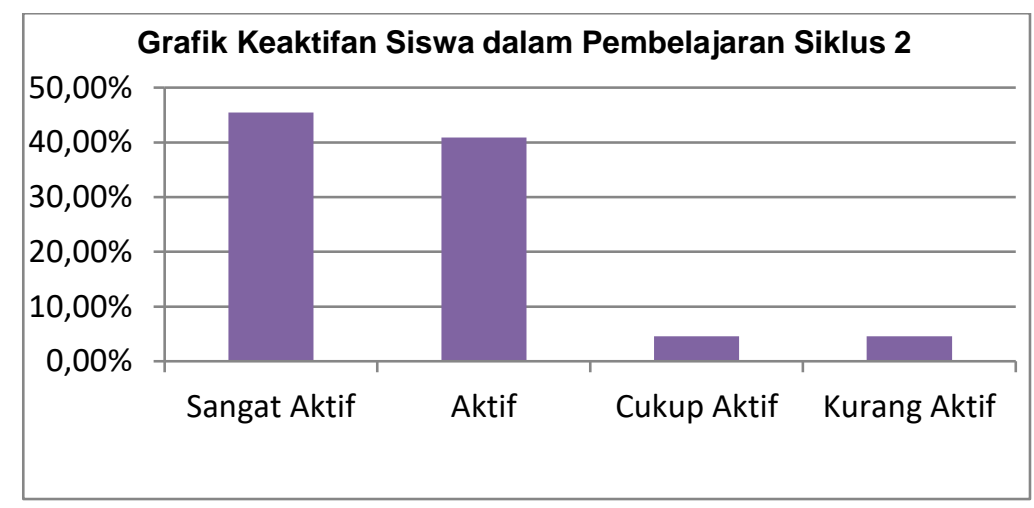


Gambar 2. Grafik Keaktifan Siswa dalam Pembelajaran Siklus 2

Dengan memperhatikan hasil penilaian selama perbaikan pembelajaran pada siklus II, dapat dilihat perkembangan hasil belajar siswa rata-rata 82,73 . Ini artinya keaktifan siswa dalam pembelajaran sudah meningkat. Kesimpulannya melalui penggunaan GoogleClassroom dalam pembelajaran dari kondisi awal dengan rata-rata 67,95 , pada siklus I diperoleh rata-rata 75,91 dan pada siklus II naik menjadi 82,73 , jadi diperoleh hasil meningkat.

Pembelajaran siklus III merupakan pengulangan pembelajaran dari hasil pembelajaran siklus II hal ini untuk mengetahui sejauh mana keaktifan siswa tidak hanya dalam pembelajaran tetapi juga dalam mengerjakan soal evaluasi. Dari hasil pengamatan diperoleh data $96 \%$ mencapai keaktifan. Adapun hasil prestasi belajar sebagai berikut

Tabel 3. Keaktifan Siswa dalam Pembelajaran Siklus III

\begin{tabular}{cccc}
\hline Interval & Frekuensi & $\%$ & Kategori \\
\hline $31-40$ & 13 & $59,09 \%$ & Sangat Aktif \\
$21-30$ & 8 & $36,36 \%$ & Aktif \\
$11-20$ & 0 & $0 \%$ & CukupAktif \\
$1-10$ & 1 & $4,55 \%$ & Kurang Aktif \\
\hline \multicolumn{2}{l}{ Rata - rata keaktifan } & 88,56 & \\
\hline
\end{tabular}

Berdasarkan tabel di atas diperoleh hasil yaitu dari 22 siswa yang memperoleh nilai 31 - 40 sebanyak 13 Siswa (59,09\%) dengan kategori sangat aktif, nilai 21 - 30 sebanyak 8 siswa (36,36\%) dengan kategori aktif, nilai $11-20$ sebanyak 0 siswa (0\%) dengan kategori cukup aktif, sedangkan 1 anak (4,54\%) dengan kategori kurang aktif. Selebihnya tergambar bahwa nilai rata-rata keaktifan siswa 88,56 dengan batas KKM 65, tingkat keberhasilan $96 \%$. Tabel diatas dapat disajikan dalam bentuk grafik. 


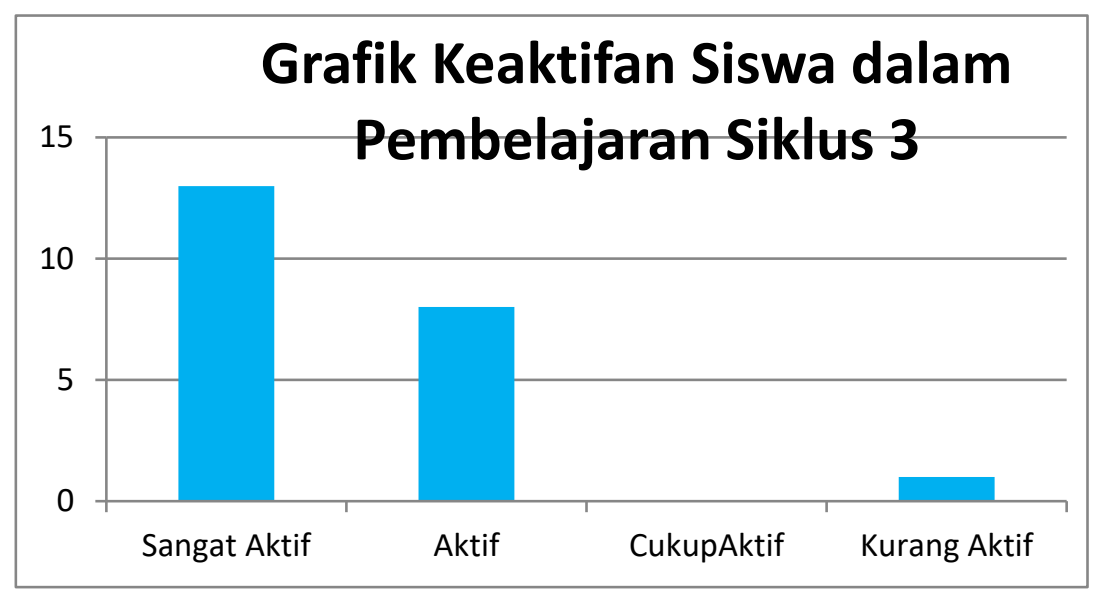

Gambar 3. Grafik Keaktifan Siswa dalam Pembelajaran Siklus 3

Dengan memperhatikan hasil penilaian selama perbaikan pembelajaran pada siklus II, dapat dilihat perkembangan hasil belajar siswa rata-rata 88,56. Ini artinya keaktifan siswa dalam pembelajaran sudah meningkat. Pada siklus 3 ini secara umum sudah bisa dikatakan menunjukkan kemajuan pada diri siswa dan nilai rata - rata siswa meningkat

\section{SIMPULAN}

Berdasarkan hasil perbaikan pembelajaran tema 4 hak dan kewajiban sub tema 1 hak dan kewajiban dirumah melalui penggunaan Google Classroom dapat diambil kesimpulan sebagai berikut : (1). Penggunaan Google Classroom dapat meningkatkan keaktifan siswa kelas III SD Muhammadiyah Purin dalam pembelajaran tema 4 hak dan kewajiban sub tema 1 hak dan kewajiban dirumah. Hal ini dapat dibuktikan dengan meningkatnya ketuntasan belajar siswa dari kondisi awal sebelum tindakan dari 22 siswa hanya 13 siswa (60\%) yang tuntas dengan KKM 65, pada perbaikan pembelajaran siklus I ketuntasan belajar siswa meningkat menjadi 17 siswa (77\%). Kemudian setelah diadakan perbaikan pembelajaran siklus II. ketuntasan belajar siswa kembali meningkat menjadi 21 siswa (94\%). (2). Pengguunaan Google Classroom dan Kahoot dapat meningkatkan minat belajar siswa kelas III semester I SD Muhammadiyah Purin Kecamatan Patebon Kabupaten Kendal dalam materi tema 4 Hak dan kewajiban sub tema 1 Hak dan kewajiban dirumah. Hal ini dapat dibuktikan dengan hasil observasi beberapa siswa kelas III SD Muhammadiyah Purin

\section{DAFTAR PUSTAKA}

Depdiknas. 2003. Undang-undang RI No. 20 tahun 2003 tentang sistem pendidikan Nasional.

Hardiyana,Andri. 2015. Implementasi Google Classroom sebagai Alternatif dalam Meningkatkan Mutu Pembelajaran diSekolah. Karya Tulis Ilmiah, Cirebon: SMA Negeri 1 Losari. 
Iqomuddin,Yazid.2013."Pengaruh Keaktifan Siswa Dalam Organisasi Disekolah Dan Belajar Siswa Terhadap

PrestasiBelajar

MatematikaKelasVIISMPN2CepuTahunAjaran2012/2013".Skripsi,

UniversitasMuhammadiyahSurakarta.http://fatkhan.web.id/pengertian-keaktifanbelajar/ (diakses tanggal 13 Oktober2020pukul14:50WIB)

https://www.pelajaran.co.id/2019/15/pengertian-ptk-tujuan-karakteristikprinsip-langkahdan-model-penelitian-tin 